dynamics Division at the National Physical Laboratory where he remained until 1961. His promotion from the junior grades to Deputy Chief Scientific Officer in 1957 was rapid and his career at the NPL spanned some of the most dramatic changes seen in aeronautics.

At the end of World War II, little was known about the behaviour of aircraft at transonic and supersonic speeds but the next decade was to change all that and Douglas Holder played an important role from the outset. The first problem was to design and build the wind tunnels which would enable the aerodynamic phenomena to be investigated. The Aerodynamics Division chose to use induced flow tunnels and a series of these ranging from the original pilot model 9 inches by 3 inches in cross section to 36 inches by 14 inches was constructed.

Before 1949 research on flow at Mach numbers close to unity had been impossible because of the refiection of the normal shock from the tunnel wall. Extensive studies of slotted walls were conducted in the UK and the USA and Holder's group at NPL made substantial contributions to this new technique which could eliminate tunnel interference effects. In addition to this work on tunnel design he made, with Gadd and Pearcey, important advances in shock wave houndary layer interaction and aerofoil design so that the division as a whole established an enviable international reputation.

Following closely on this pioneering research on transonic and supersonic aerodynamics Holder next led the development of a series of shock and wind tunnels for the study of flight at hypersonic speeds, i.e. above about Mach 7. Completely new techniques were needed to drive such facilities and Holder, now head of all high speed aerodynamics at NPL, took a major role in planning and designing these devices. The flow durations in shock tubes and shock tunnels range from tens of microseconds to a few milliseconds but Holder was equally at home in this new field. He had very early demonstrated a highly developed skill in wind tunnel design and had the ability, which may be the mark of the true engineer, to make rapid estimates of all the important design parameters for a new facility. Throughout this period he published, as he had always done, widely, and some of his papers are classics of their kind.

In 1961 he was invited to lake the Chair of Engineering Science at Oxford to succeed Thom who was then retiring, and became at 37 the fourth holder of that post. The early sixties saw in Oxford, as in the UK as a whole, a rapid expansion of university engineer- ing departments and under Thom a major development had been initiated. Holder took over this work and guided it through to completion. Although he continued to take a keen interest in fluid dynamics he also saw the importance of maintaining and extending a broad base of knowledge and there are now two new chairs in structures and electricity, largely due to his foresight and persistence.

His long association with aeronautics at the NPL made him an obvious choice as a consultant for industry and government and he was also much in demand in educational establishments. He was elected FRS in 1962 and served on many of its committees as well as its Council between 1969 and 1971. His wide range of activities outside Oxford constantly suggested new lines of research and development and together with Professor R. B. Duthie he established in Oxford a centre for orthopaedic engineering and encouraged work in physiological fluid dynamics.

Outside of Oxford his government advisory work was at the highest level and must remain obscured by confidentiality although he will be remembered for his chairmanship of the enquiry into Precision Approach Radar following the Gatwick disaster in 1969 and later, in 1971, his involvement at ministerial level in the technical decisions on the future of the RB-211 engine.

By nature he was reserved and the extent of his influence in both aeronautics research and engineering education is a testimony more to his patient and persuasive skills than to any justifiable forcefulness in argument. $\mathrm{He}$ was an exceptionally able administrator and dealt with what would appear a crippling work load with quiet efficiency. He was always ready to listen to his staff and research students and to encourage them to pursue new lines of investigation and he was generous to a fault to those who were in difficulties, although few around him would be aware of his very personal interventions. In this respect he was particularly effective on the University Staff Committee where he will long be remembered for his patient and skilful administration.

In his views of the part that universities should play in the industrial life of the country he was ahead of his contemporaries and with such wide experience and extensive contacts he often put his finger on promising lines of new work long before they were apparent to others. There are, alas, only a few of his calibre and he will be sadly missed in both university and industrial bodies.

D. L. Schultz

\section{Yves Guitton}

Professor Yves Guitton died on 6 July 1977 in Perpignan (France) at the age of 46. He leaves a wife and two sons. Head of the Laboratory of Plant Physiology, he was also chairman of the University Group for the Biology of Development and Parasitology and Vice-president of the University of Perpignan.

With a wide-ranging scientific background, involving organic chemistry, nuclear energy research and microbiology, he entered plant physiology and biochemistry because he felt the development of this field to be essential for the future. His doctoral thesis was devoted to the metabolism of arginine during the germination of Pinus, and his contribution to the study of amino acids and nitrogenous substances was invaluable to French biochemistry.

In 1966 he was appointed to the newly-created University of Perpignan, addressing himself to a problem which intrigued him: the role of nucleic acids in developmental processes. Arriving alone in his new laboratory, geographically isolated from the scientific community, Professor Guitton nevertheless created within ten years a laboratory equipped for all techniques of molecular biology. The research team which he built up is a leading group in Firench physiology, collaborating with others both at home and abroad.

His recent contributions concern the metabolism of mRNA during the first hours of seed germination, mRNA stability and developmentrelated changes in chromatin structure and composition. With his collaborators he was the author of around fifty publications in French and international journals.

In addition to his brilliant scientific career he involved himself with equal enthusiasm in his outside interests. An excellent footballer in his youth, he turned his attention to tennis after a serious accident, rapidly reaching a high standard. Many will remember his arrival at scientific conferences complete with tennis racquet, looking for partners among his American and British colleagues. In politics he was a highly active member of the Socialist party, deeply involved in the problems of his city.

For those who knew him Yves Guitton will be remembered not only for his exceptional achievements, but perhaps even more for his enthusiastic approach to all which concerned him and his warmth and friendliness in any company. His premature loss will be deeply regretted by his many friends in the scientific community and in his city. Michel Delseny 